\title{
sciendo
}

\section{COMPARATIVE ANALYSIS OF LOCAL COMMUNITY PROTECTION MECHANISMS IN KOSOVO AND NORTH MACEDONIA}

\author{
PhD. Cand. Artan Binaku, \\ Faculty of Contemporary Social Sciences, \\ South East European University, Tetovo, North Macedonia \\ artan.binaku@gmail.com \\ Assoc. Prof. Memet Memeti, \\ Faculty of Contemporary Social Sciences, \\ South East European University, Tetovo, North Macedonia \\ m.memeti@seeu.edu.mk
}

\begin{abstract}
The objective of this paper is to provide a comparative analysis of local community protection mechanisms in Kosovo and North Macedonia. The intention is to comparatively analyze the community protection mechanism's differences and similarities and their establishment in both countries. Requirements on community protection mechanisms as tools for ensuring community rights will be elaborated with two institutional settings and succinct legal infrastructure. The establishment of the community-led mechanisms debate has been increasingly conductive to Kosovo and North Macedonia since the inter-ethnic conflicts that these two states were involved in. For that particular reason, Kosovo and North Macedonia have initiated the design of community protection mechanisms to foster inter-community communication, tension easing, and serving as a means and tool for communities' inclusiveness in local and central institutional affairs.
\end{abstract}


In doing this analysis, two primary legal documents in Kosovo and North Macedonia, the proposed plan settlement of the former United Nations special envoy Martii Ahtisaari in Kosovo and the Ohrid Framework Agreement in North Macedonia, will lead to conclusive comparative findings. Further, the comparative analysis will extend to elaborating Kosovo's and North Macedonia's legislative framework, such as their constitutions, community protection laws, and local governance legislation.

The importance of the paper also extends to comparing the community protection mechanisms between two countries in finding potential differences and parities between the community protection mechanisms in Kosovo and North Macedonia.

Finally, the analysis will provide a theoretical understanding of the local community protection mechanisms framework, focusing on establishing community protection mechanisms, legal requirements, and successes these mechanisms have brought to both countries' institutional settings.

Keywords: Community Protection Mechanisms, Legislation, Comprehensive Proposal, Ohrid Framework Agreement.

\section{INTRODUCTION}

Globally speaking, community protection mechanisms are a relatively new concept used to promote community inclusion and have different aspects, including political, social, ethnic, or religious characteristics. Universally, community protection mechanisms are understood as tools and means of protecting socially vulnerable groups, such as children, women, persons with disabilities, and other socially powerless individuals. Community protection is a vague concept in the local and regional context and has not been elaborated in terms of ethnicity, race, or religion.

Worldwide, the following are organizations that have elaborated the community protection: The United Nations with its Declaration on the Rights of Persons Belonging to National or Ethnic, Religious and Linguistic Minorities, the International Covenant on Civil and Political Rights (ICCPR) and the International Covenant on Economic, Social and Cultural Rights. Besides, regional European treaties such as the European Convention on Human Rights, the Framework Convention for the Protection of National Minorities will be referenced to make the comparison properly. In addition to the above, this paper will also recognize authors on community protection and engagement such as Kegler, Steckler, McLeroy, \& Malek, Robinson \& White. Mechanisms are also seen as a method of inclusive and power- 
sharing principle, a technique that political scientist Arend Lijphart developed, where he states 'that is a system of rule in societies divided along ethnic, religious, or cultural lines, which posits the basic idea of managing the differences by providing power guarantees to each significant identity group' (Lijphart, 1977).

For this particular analysis and comparison, we will refer to community protection mechanisms with this definition as 'tools, methods, legislation/instruments that Kosovo and North Macedonia use to promote community rights and interests of particular ethnic community groups.' The definition mentioned above has been developed as part of the Ph.D. thesis by one of the paper authors.

Both Kosovo and North Macedonian legislations do refer to communities, but they do not provide a clear understanding of what it exactly means and entails. One must recognize that both countries have made significant progress in drafting and approving legislation to improve community affairs and rights through primary and secondary legislation. As stated above, the paper will compare both countries' institutional and legislative settings in finding out the similarities of community protection mechanisms, how they function, their duties and responsibilities (terms of references), and how many local community protection mechanisms exist in Kosovo and North Macedonia.

The idea of the creation of community mechanisms is seen as a method of inclusive and power-sharing principle. Political scientist Arend Lijphart developed this technique. He states that it is a system of rule in societies divided along ethnic, religious, or cultural lines, positing the basic idea of managing the differences by providing power guarantees to each significant identity group' (Lijphart, 1977). Lijphart's theory on 'consociational democracy involves two important pillars of democracy, which includes mutual veto, i.e., the consensus among the groups is required to confirm the majority rule, where mutuality means that the minority is unlikely to block the majority successfully_-if one group blocks another on some matter, the latter is likely to block the former in return. Proportionality, i.e., representation, is based on population - if one pillar accounts for $30 \%$ of society, they occupy $30 \%$ of the police force's positions, in civil service, and other national and civic segments of society' (Lijphart, 1977)

In Kosovo's case, the last census organized in $2011,7.1 \%$ of country populations are from communities (Kosovo Agency of Statistics 2011). The census of 2002 in North Macedonia revealed that more than $35 \%$ of the country's population is from other communities (Macedonian State Statistical Office 2002). 
In promoting democracy and inclusiveness at central level, i.e., at Kosovo's parliament, according to Kosovo's Constitution and Ahtisaari's plan, out of 120 seats at the parliament, was 20 seats have been reserved for communities. Kosovo's constitution states that ten seats are reserved for Kosovo Serb community. The remaining ten seats are reserved for Kosovo's remaining communities, such as Kosovo Roma, Kosovo Ashkali, Kosovo Egyptian, Kosovo Bosnian, Kosovo Turk, and Kosovo Gorani community. In Kosovo, the communities' rights are further enhanced and guaranteed, there can be no constitutional changes if Kosovo communities do not endorse the constitutional changes. Article 144, paragraph 2 of the Kosovo Constitution stipulates that any amendment shall require for its adoption the approval of two thirds (2/3) of all MPs of the Assembly, including two thirds (2/3) of all MPs of the Assembly holding reserved or guaranteed seats for representatives of communities that are not in the majority in the Republic of Kosovo'. (Constitution of Kosovo, 2008).

In North Macedonia, on the other hand, no reserved seats have been foreseen for communities, a relatively significant difference to Kosovo.

Kosovo's structure on community mechanisms has its roots in UNMIK Regulation 2000/45 on Self-Government of Municipalities in Kosovo and subsequent administrative instructions, while the latest system of Kosovo's legal obligation and institutional setting of community protection mechanism derive from the Ahtisaari Plan. The Ahtisaari plan, formally known as the Comprehensive Proposal for the Kosovo Status Settlement, is a status settlement proposal covering a wide range of issues related to the Kosovo status process for Kosovo (United States Department of State, 2008). The same document introduced constitutional provisions, rights of communities and their members, decentralization of local government and justice system. Just after the Declaration of Kosovo's independence from Serbia on February 17, 2008, on April 7, the Kosovo parliament approved the constitution and subsequent laws regulating governance, rights and obligations of its citizens and the protection and promotion of human rights (Kosovo Constitution, 2008).

Several laws were approved addressing community rights, such as the Law on the Use of Languages, the Law on the Protection and Promotion of the Rights of the Communities and their Members in Kosovo, the Anti-Discrimination Law, the Law on Education in the Municipalities, the Law on the Civil Service, the Law on Local Elections, the Law on General Elections, the Law on Education, the Law on Kosovo Radio Television, the Law on Cultural 
Heritage, the Law on the Establishment of Special Protective Zones and finally the Law on Local-Self Government.

In North Macedonia, the Ohrid Framework Agreement (OFA) laid the foundations for promoting its citizens' peace and cohabitation. The agreement intended that the communities residing in North Macedonia will reach peace and stability through OFA, by respecting ethnic communities and their national identity. In comparison to the Ahtisaari plan, OFA was not intended to finalize the future status of North Macedonia. Instead, it was designed to stop the inter-ethnic conflict and tensions between ethnic Albanians and ethnic Macedonians. As rightly pointed out by Florian Bieber and Veton Latifi, 'the main goal of the Ohrid Framework Agreement was to accommodate the grievances of the Albanian community while at the same time address the concerns of the Macedonian majority by preserving the territorial integrity of the unitary state (Bieberr, 2005; Latifi, 2001)'.

Compared to the Ahtisaari plan, the OFA agreement was a combination of measures designed to favor multi-ethnicity and the integration of ethnic communities (equitable representation in public administration and enterprises, parliamentary and municipal committees on inter-ethnic relations) (Lyon 2011). While the Ahtisaari Plan set out state requirements to Kosovo institutions in community protection, it also paved the road to removing Kosovo's supervised independence.

OFA also foresaw reforms that institutionalize the social and cultural distance that already existed between the different communities (enhanced language rights, municipal decentralization, and special voting procedures) (Ragaru, 2008).

Like the Ahtisaari proposal, OFA aimed at society's multi-ethnic nature strives to improve public life and local government reform and encourage citizen participation in public life through the introduction of new mechanism and legislation. The OFA incorporated constitutional changes, and it changed the use of terminology on communities, i.e., 'other nationalities' was replaced with the 'communities' in the constitution. In the pre-November 2001 constitution, the state was not de-facto and de-jure recognized as a state of all its citizens; somewhat, it qualified the Republic of Macedonia as a state consisting of Macedonians. The constitutional changes in 2001 also introduced the fact that a language spoken by at least $20 \%$ of its citizens shall be considered an official language; it also aims at equitable representation of communities in public institutions and public life. The OFA agreement also aims at fostering ethnic protection of its communities, their linguistic and religious identity, and further use of 
their national symbols. In making sure that these rights are fully respected and further enhanced, a double majority voting principle was introduced when approving laws that affect communities' rights. Finally, and most notably, the changes introduced established the Parliamentary Committee responsible for community issues and providing advice and solutions in matters concerning communities residing in North Macedonia.

\section{The comparison of the framework of community protection mechanisms in Kosovo and North Macedonia}

\section{Central level institutions}

\begin{tabular}{|c|c|}
\hline $\begin{array}{l}\text { Kosovo-Central Level institutions on community } \\
\text { protection }\end{array}$ & $\begin{array}{l}\text { North Macedonia- Central Level institutions on } \\
\text { community protection }\end{array}$ \\
\hline $\begin{array}{l}\text { 1. Double minority vote (constitutional } \\
\text { changes) }\end{array}$ & 1. Double minority vote \\
\hline $\begin{array}{l}\text { 2. Consultative Council for Communities } \\
\text { (CCC) at the office of the President }\end{array}$ & 2. Ombudsperson institution \\
\hline 3. Ombudsperson institution & $\begin{array}{l}\text { 3. Agency for the fulfillment of rights of } \\
\text { communities }\end{array}$ \\
\hline 4. Ministry for communities and return & \\
\hline $\begin{array}{l}4 \text { Committee on human rights, petition and } \\
\text { antidiscrimination }\end{array}$ & \\
\hline $5 \quad$ Human rights units within ministries & \\
\hline
\end{tabular}

\section{Local Level institutions}

\begin{tabular}{|c|c|}
\hline $\begin{array}{l}\text { Kosovo-Local Level institutions on } \\
\text { community protection }\end{array}$ & $\begin{array}{l}\text { North Macedonia- Local Level } \\
\text { institutions on community protection }\end{array}$ \\
\hline $\begin{array}{l}\text { 1. Municipal Offices for Communities and } \\
\text { Return }\end{array}$ & $\begin{array}{l}\text { 1.Committees for Inter-Community Relations' } \\
\text { (CICR) }\end{array}$ \\
\hline 2. Communities Committees & \\
\hline 3. Deputy Mayor for Communities & \\
\hline 4. Municipal Community Safety Councils & \\
\hline $\begin{array}{l}\text { 5. Deputy Chairpersons for the Municipal } \\
\text { Assembly for Communities }\end{array}$ & \\
\hline
\end{tabular}




\section{Duties and responsibilities of local community protection mechanisms}

\section{Kosovo}

\section{- Municipal Office for Communities and Return}

All municipalities in Kosovo have a legal duty to establish MOCRs. Responsibilities of the MOCR include protecting and promoting communities' rights, ensuring equal access to services, and enabling conditions for the sustainable return of displaced persons. MOCRs are mandatory for all municipalities in Kosovo. (OSCE, 2015) MOCRs had been established in 2010, and since 2015, 34 out of 38 municipalities in Kosovo have established their offices. Four municipalities that have not established MOCRs in 2015 have been northern municipalities of Kosovo, resided by Kosovo Serb communities.

\section{- Communities Committees}

All municipalities have a legal obligation to establish a Committee for Communities in Kosovo (Article 53 of the Law on Local Self-Government). The Communities Committee is set in 38 municipalities of Kosovo; 37 of the 38 committees meet regularly (only the committee from the municipality of Kamenica has not fulfilled its obligation. The CC's duties include reviewing municipal policies, practices, and activities, ensuring that communities' interests are safeguarded. Ensure that communities respect communities' rights and interests and ensure they adhere to those applicable laws that protect their rights and interests. Review the municipality's annual draft budget and advocate or include provision and funds for activities that aim to promote fairness. Recommend measures to the municipal Assembly and Mayor on issues and activities affecting communities and advocate for equal community representation within the municipal civil service.

\section{- Deputy Mayor for Communities}

The DMC post is a mechanism that is obligatory in municipalities where a minority community makes up at least $10 \%$ of the municipality's population. (OSCE, 2017) Municipalities with less than $10 \%$ of communities can also be established upon the municipal Assembly's decision. The DMC is mandated to provide advice and guidance to the Mayor on community issues and represent all communities residing in the municipality. DMC candidate is proposed by the Mayor and approved by the municipal Assembly. (OSCE, 2017) The DMC 
is mandated to provide advice and guidance to the Mayor on community issues and represent all communities residing in the municipality (OSCE, 2017) Duties of the DMC include supporting communities' requests to municipal bodies, undertaking outreach to communities, ensuring that municipal executive implements projects activities, policies and regulation related to the protection and promotion of communities rights. DMC has a core role in the municipality to promote inter-community dialogue, promote confidence-building between communities and municipal institutions, and ensure that sufficient funding is allocated for communities and their rights. (OSCE, 2017)

\section{- Municipal Community Safety Councils}

All municipalities have a legal obligation to establish the Municipal Community Safety Councils. The main reason why the MCSC is established is to improve and enhance community safety and security. Among other issues, they discuss security concerns, share recommendations on security improvement, and serve as a forum for cross-sectional cooperation and information sharing. An OSCE report issued states that during the MCSC term 2014-2017, out of Kosovo's 38 municipalities, the forum was established in 34 municipalities.

\section{- Deputy Chairpersons for the Municipal Assembly for Communities}

The Deputy Chairperson of the Municipal Assembly for Communities is a position defined in the Constitution of the Republic of Kosovo (article 62 of the Constitution of the Republic of Kosovo, Law on Local Self Government (No.03/L-040, 2008) Article 55; DCMAC Guidelines) and municipal statute in municipalities where at least $10 \%$ of citizens belong to non-majority communities. It aims to promote inter-community dialogue and serve as a formal focal point for addressing the concerns and interests of all non-majority communities at Municipal Assembly meetings. This mechanism is also mandated to promote inter-community dialogue and serve as a contact point for communities' issues (OSCE, 2015).

\section{North Macedonia}

\section{- Committees for Inter-Community Relations' (CICR)}

The existence of legal provisions that regulate the CICRs in North Macedonia are set in the Law on the Local Self Government adopted in 2002. The Law governs these CICRs with articles 41 and 55, which specify the work, mandate, membership, functionality, and CICRs resulting from the decentralization process in North Macedonia, part of the Ohrid Framework Agreement (OFA). These committees have been created to represent equitable representation 
in the public institutions, both local and stipulates that in municipalities where at least $20 \%$ of the citizens are of an ethnic background different from the majority population, such a commission should be established. (Law on Self-Government in Macedonia, 2002) In the Republic of North Macedonia, 20 municipalities should create the CIRC commissions. Those municipalities are listed below: Brvenica, Vraneshtica, Debar, Dolneni, Zelenikovo, Jegnunovce, Kicevo, Krushevo, Kumanovo, Mavrovo and Rostushe, Petrovec, Sopishte, Struga, Tetovo, Chashka, Chucher Sandevo, Skopje, Butel, Chair and Shuto Orizari.

\section{CONCLUSION}

After the detailed elaboration of legal requirements, legal structure, and the existence of the local community protection mechanisms in Kosovo and North Macedonia, conclusive evidence shows significant differences between the two. Findings of the review of community protection definitions show that both countries have legislation to promote and protect communities' rights. Both Kosovo and North Macedonia legislation refer to international treaties and conventions. They have used these guiding treaties to advance community rights and interests of particular ethnic community groups in line with the Declaration's requirements on the Rights of Persons Belonging to National or Ethnic, Religious and Linguistic Minorities. However, Kosovo is not a member of the United Nations or Council of Europe; Article 22 of the Kosovo Constitution refers to international agreements and instruments' direct applicability. In case of conflict between domestic and international instruments, international instruments have priority over local legislation of acts of public institutions.

Both Kosovo and North Macedonian legislation refer to communities, but they do not clearly and succinctly provide an understanding of what it exactly means and entails. In Kosovo, at least 12 Laws regulate community protection at the central and local levels. Those are the Law on the Use of Languages, the Law on the Protection and Promotion of the Rights of the Communities and their Members in Kosovo, the Anti-Discrimination Law, the Law on Education in the Municipalities, the Law on the Civil Service, the Law on Local Elections, the Law on General Elections, the Law on Education, the Law on the Kosovo Radio Television, the Law on Cultural Heritage, the Law on the Establishment of Special Protective Zones, and the Law on Local Self-Government. In North Macedonia, the laws in question include: the Law on Local Self-Government, the Law on the Use of Flags of the Communities, the Law on the 
Promotion and Protection of the Rights of the Members of the Communities which are less than $20 \%$ of the population in the Republic of Macedonia.

According to the applicable legislation, there are five community protection mechanisms that municipalities must establish at the local level in Kosovo. Out of these five mechanisms, three (CC, MCSC and MOCR) are mandatory for all 38 municipalities in Kosovo. Simultaneously, establishing the DCMAC and DMC position is obligatory only for municipalities where at least $10 \%$ of citizens belong to Kosovo's non-majority communities (Law on Local-Self Government in Kosovo, 2008). In North Macedonia, there is only one community protection mechanism established at the local level, which differentiates hugely from those in Kosovo in terms of legal requirement and functionality. The CIRC establishment legal requirements are relatively legally optional compared to Kosovo and are a requirement of municipalities where at least $20 \%$ of the citizens are of an ethnic background different from the majority population (the Law on the Promotion and Protection of the Rights of the Members of Communities which are less than $20 \%$ of the Population of the Republic of Macedonia, 2008). The CIRC in North Macedonia is an equivalent community protection mechanism to the $\mathrm{CC}$ in Kosovo, but as stated above, duties and responsibilities differ hugely. In addition to the above, in Kosovo, some mono-ethnic municipalities have established community protection mechanisms, although they are not legally required to do so. This has been precisely the case of municipalities of Hani i Elezit and Kaçanik. 


\section{SEEU Review Volume 16 Issue 1}

\section{REFERENCES}

1. Baldwin, C. (2006). Minority rights in Kosovo under international rule. London: Minority Rights Group International.

2. Beha, A. (2014). Minority rights: An opportunity for adjustment of ethnic relations in Kosovo. JEMIE, 13, 85.

3. Bieber, F. (2004). Institutionalizing ethnicity in the Western Balkans: managing change in deeply divided societies.

4. Bieber, F. (2005). Partial implementation, partial success: The case of Macedonia. New challenges for power-sharing: Institutional and social reform in divided societies, 107-122.

5. Brancati, D. (2009). Peace by design: Managing intrastate conflict through decentralization. Oxford University Press.

6. Brinkerhoff, DW (Ed.). (2007). Governance in post-conflict societies: Rebuilding fragile states. Routledge.

7. Brown, K., Farisides, P., Ordanoski, S., \& Fetahu, A. (2002). Ohrid and beyond: A Cross-Ethnic Investigation into the Macedonian Crisis. London: Institute for War and Peace Reporting.

8. Brunnbauer, U. (2002). The implementation of the Ohrid agreement: ethnic Macedonian resentments. JEMIE, 1.

9. Caca, G. (1999). Status and Rights of Nationalities in the Republic of Macedonia. In The new Macedonian question (pp. 148-164). Palgrave Macmillan, London.

10. Calu, M. I. (2018). Unintended consequences of state-building and the management of diversity in post-conflict Kosovo. Nationalities papers, 46(1), 86-104.

11. Caplan, R., \& Caplan, R. D. C. (2005). International governance of war-torn territories: rule and reconstruction. Oxford University Press.

12. Daskalovski, Ž. (2006). Walking on the edge: consolidating multi-ethnic Macedonia, 1989-2004. Globic Press.

13. Dimitrova, K. R. (2004). Municipal decisions on the border of collapse: Macedonian decentralisation and the challenges of post-Ohrid democracy. Southeast European Politics, 5(2-3), 172-86. 
14. Dimova, N. (2008). Identity of the nation (s), identity of the state: politics and ethnicity in the Republic of Macedonia, 1990-2000. Ethnologia Balkanica, (12), 183-213.

15. Dursun-Ozkanca, O., \& Crossley-Frolick, K. (2012). Security sector reform in Kosovo: the complex division of labor between the EU and other multilateral institutions in building Kosovo's police force. European security, 21(2), 236-256.

16. Ernst, A. (2014). The April Agreement-A Step towards Normalization between Belgrade and Pristina?. Contemporary Southeastern Europe, 1(1), 122-126.

17. Hehir, A. (Ed.). (2010). Kosovo, intervention and statebuilding: the international community and the transition to independence. Routledge.

18. Lijphart, A. (1977). Democracy in plural societies: A comparative exploration. Yale University Press.

19. List, G. (2010). Accordance with International Law of the Unilateral Declaration of Independence in Respect of Kosovo. THE REVIEW OF INTERNATIONAL AFFAIRS , 143.

20. Lončar, J. (2016). State-building and local resistance in Kosovo: Minority exclusion through inclusive legislation. Communist and Post-Communist Studies, 49 (3), 279290.

21. Lyon, A. (2011). Municipal Decentralization in the Republic of Macedonia: Preserving a Multi-Ethnic State?. Federal Governance, 8(3).

22. Lyon, A. (2012). Between the integration and accommodation of ethnic difference: Decentralization in the Republic of Macedonia. JEMIE, 11, 80.

23. Maleska, M. (2005). What kind of a Political System did Macedonia get after the Ohrid Peace Agreement. New Balkan Politics, 9, N_A.

24. Maleska, M., Hristova, L., \& Ananiev, J. (2006). Power Sharing-New Concept of Decision Making Process in Multicultural Municipalities. Association for Democratic Initiative.

25. Official Gazette of the Republic of Kosovo (2008), Law on the Protection and Promotion of the Rights of the Communities and their Members in Kosovo, Government of Republic of Kosovo: Pristina

26. Official Gazette of the Republic of Kosovo (2008), Constitution of the Republic of Kosovo, Government of Republic of Kosovo: Pristina

27. Official Gazette of the Republic of Kosovo (2008), Law on Cultural Heritage, Government of Republic of Kosovo: Pristina 
28. Official Gazette of the Republic of Kosovo (2008), Law on Education in the Municipalities, Government of Republic of Kosovo: Pristina

29. Official Gazette of the Republic of Kosovo (2008), Law on Local Self Government (No. 03/L-040, 2008), Government of Republic of Kosovo: Pristina

30. Official Gazette of the Republic of Kosovo (2008), Law on the Civil Service, Government of Republic of Kosovo: Pristina

31. Official Gazette of the Republic of Kosovo (2008), Law on the Establishment of Special Protective Zones, Government of Republic of Kosovo: Pristina

32. Official Gazette of the Republic of Kosovo (2008), Law on the Protection and Promotion of the Rights of the Communities and their Members in Kosovo, Government of Republic of Kosovo: Pristina

33. Official Gazette of the Republic of Kosovo (2008), Law on Use of Languages, Government of Republic of Kosovo: Pristina

34. Official Gazette of the Republic of Kosovo (2008), The Anti-Discrimination Law, Government of Republic of Kosovo: Pristina

35. Official Gazette of the Republic of Macedonia (1995), Law on Local Self Government No.52/1995. Government of the Republic of Macedonia: Skopje.

36. Official Gazette of the Republic of Macedonia (1996) Law for the Territorial Division of the Republic of Macedonia and the Units of Local Self-Government No.49/1996. Government of the Republic of Macedonia: Skopje

37. Official Gazette of the Republic of Macedonia (2001a) Constitution of the Republic of Macedonia. Government of the Republic of Macedonia: Skopje

38. Official Gazette of the Republic of Macedonia (2001b) Framework Agreement. Government of the Republic of Macedonia: Skopje

39. Official Gazette of the Republic of Macedonia (2002), Law on Local Self Government No. 5/2002. Government of the Republic of Macedonia: Skopje

40. Official Gazette of the Republic of Macedonia (2005), Law on the Use of Flags of the Communities in the Republic of Macedonia. Government of the Republic of Macedonia: Skopje

41. Official Gazette of the Republic of Macedonia (2007) Law on the Committee for Relations between the Communities No. 150/2007. Government of the Republic of Macedonia: Skopje 
42. Official Gazette of the Republic of Macedonia (2007) Law on the Committee for Relations between the Communities No. 150/2007. Government of the Republic of Macedonia: Skopje

43. Official Gazette of the Republic of Macedonia (2008a) Law on the Promotion and Protection of the Rights of the Members of Communities which are Less than $20 \%$ of the Population of the Republic of Macedonia No. 92/2008. Government of the Republic of Macedonia: Skopje

44. Official Gazette of the Republic of Macedonia (2008a) Law on the Promotion and Protection of the Rights of the Members of Communities which are Less than $20 \%$ of the Population of the Republic of Macedonia No. 92/2008. Government of the Republic of Macedonia: Skopje

45. Official Gazette of the Republic of Macedonia (2008b) Law on the Use of Languages Spoken by at least $20 \%$ of the Citizens in the Republic of Macedonia and in the Units of Local Self-Government. Government of the Republic of Macedonia: Skopje

46. Official Gazette of the Republic of Macedonia (2008b) Law on the Use of Languages Spoken by at Least $20 \%$ of the Citizens in the Republic of Macedonia and in the Units of Local Self-Government. Government of the Republic of Macedonia: Skopje

47. Ordanoski, S., \& Matovski, A. (2007). Between Ohrid and Dayton: The future of Macedonia's framework agreement. South East Europe Communications, 4 (4), 4659

48. Organization for the Security and the Cooperation in Europe (OSCE),(2013). Representation of communities in the civil service in Kosovo.

49. Organization for the Security and the Cooperation in Europe (OSCE), (2019). Mechanisms for the Protection and Promotion of Communities Rights- Information Sheets.

50. Perritt Jr, H. H. (2010). The road to independence for Kosovo: a chronicle of the Ahtisaari plan. Cambridge University Press.

51. Popovska, B. (2012). The role of teaching history for a nation-building process in a post-conflict society: The case of Macedonia. Connections, 12(1), 51-64.Ragaru, N. 2008, Macedonia:

52. Stevens, G. (2009). Filling the vacuum: ensuring protection and legal remedies for minorities in Kosovo. London: Minority Rights Group International. 
53. Strøm, K., Gates, S., Graham, B., \& Strand, H. (2017). Inclusion, dispersion, and constraint: power-sharing in the world's states, 1975-2010. British Journal of Political Science, 47(1), 165-185.

54. United Nations (1976) International Covenant on Economic, Social and Cultural Rights, New York city, United Nations General Assembly.

55. United Nations (1992), Declaration on the Rights of Persons Belonging to National or Ethnic, Religious and Linguistic Minorities, New York city, United Nations General Assembly.

56. United Nations (1999), United Nations Mission in Kosovo Regulation No. 2000/45 on Self-Governement of Municipaliteis in Kosovo. United Nations.

57. United Nations (2010), Programme to Enhance Inter-Ethnic Dialogue and Collaboration. Results of a Participatory Assessment National and Local Capacities for Strengthening Inter-Ethnic Dialogue and Collaboration, Skopje: UN.

58. Vankovska, B. (2006). The role of the Ohrid Framework and the peace process in Macedonia. Transnational Foundation for Peace and Future Research, 9 , 1-26.

59. Weller, M. (2009). Settling self-determination conflicts: Recent developments. European Journal of International Law, 20(1), 111-165.

60. Wilmer, F. (2006). Minority Rights and Charles Tilly's Stateness (No. p0016). University of Hamburg, Faculty for Economics and Social Sciences, Department of Social Sciences, Institute of Political Science. 